\title{
Hediye, Denetçi, Bağımsızlık Sarmalı
}

\author{
Gift-giving, Auditors, and the Independence Spiral
}

\author{
Süleyman Yükçü̈ ${ }^{1}$, Sevda Anlı² $®$ \\ 'Prof.Dr., Dokuz Eylül Üniversitesi, Sosyal Bilimler Enstitüsü Muhasebe ve Finansman, İzmir, Türkiye. Eposta: suleyman.yukcu@deu.edu.tr \\ ${ }^{2}$ Dokuz Eylül Üniversitesi Sosyal Bilimler Enstitüsü, Muhasebe, İzmir, Türkiye. Eposta: sezersevda35@gmail.com
}

ORCID: S.Y. 0000-0002-1514-5953; S.A. 0000-0003-0195-1230

\section{öz}

Bağımsız denetim, finansal tabloların genel kabul görmüş muhasebe standartlarına uygunluğunun, doğruluğunun ve güvenilirliğinin bağımsız bir şekilde denetiminin yapılmasıdır. Bağımsız denetçi, denetim mesleğini icra ederken mesleki etik ilkelerine uygun hareket etmelidir. Bu bağlamda, bağımsız denetçilerin uyması gereken mesleki etik ilkeleri; dürüstlük, tarafsızlık, mesleğe uygun davranış, sır saklama ve mesleki yeterlilik ve özendir. Tarafsızlık ilkesi kapsamında denetçinin; kişisel çıkarlar, müşterilerle yakın ilişki, müşterilerin denetçinin kendi görüşlerini benimsemesini sağlama çabaları vb. durumlar tarafsız karar vermeyi etkileyebilir. Bu tür durumlarda denetçi, mesleki faaliyetini mesleki etik ilkelerine ve tarafsızlık ilkesine aykırı olarak gerçekleştirir. Bu duruma sebep olabilecek olaylardan biri de hediye alışverişidir. Yapılan çalışmada, hediye kavramı açıklanmış olup denetçiler ve bağımsız denetim kapsamında hediye bağlamı değerlendirilmiştir. Bu doğrultuda etik konusu çerçevesinde mevcut konu, literatürde yer alan veriler doğrultusunda incelenmiştir. Elde edilen verilere göre denetim müşterisinden denetim personeline ağırlanma teklifi, yemek yeme teklifi veya hediyelerin kabul edilmesi kişisel çıkar veya yakınlık tehdidi oluşturabilir. Denetçi bağımsız ve temel etik ilkelere bağlı kalarak bir şirketi denetlemesi gerekli olup, şirket tarafından hiçbir şekilde hediye kabul etmemelidir. Denetçi, birçok ülkede kanunla yasaklanmış olan teşviklere ve hediyelere dikkat etmelidir. Çünkü denetçinin etik olmayan davranışa neden olan bir teşviki veya hediyeyi kabul etmesi veya sunması dürüstlük ilkesini ihlal eder. Bu bağlamda, teşvikin niteliğine, sıklığına, değerine, kültürel etkisine, şeffaflığına ve denetim müşterisinin bu tür davranışları mesleki muhakemeyle değerlendirmesine dikkat edilmelidir. Teşvikin davranışı olumsuz etkilediği tespit edilirse, firma veya müşteri iş yönetimini bilgilendirmek ve iş ilişkisini sonlandırmak gibi önlemler alınmalıdır.

Anahtar kelimeler: Hediye, Denetçi, Bağımsızlık Sarmalı

\section{ABSTRACT}

An independent audit refers to the objective examination of financial statements' compliance by an autonomous individual using generally accepted accounting standards to assess accuracy and reliability. The independent auditor must act in accordance with the principles of professional ethics in the process of performing audits. In this context, the professional ethical principles with which independent auditors must comply include honesty, impartiality, professional behavior, confidentiality, professional competence, and care. In the scope of the principle of impartiality, the auditor's selfinterest, a close relationship with clients, efforts of clients to get an auditor to adopt their own views, and other potentially compromising situations can affect impartial decision making. In such cases, the auditor performs professional activity in violation of the principles of professional ethics and impartiality. A circumstance that can cause such situations is that of gift-giving. In this study, the concept of gifts is explained, and the context of giftgiving is evaluated within the scope of auditors and independent audits. Within the framework of ethics, the issue of gift-giving is examined referencing preexisting data in the literature. According to the data obtained, hospitality offers, meal offers, or acceptance of gifts given by an audit client to an independent auditor may result in self-interest or familiarity threats. As an auditor must perform audits independently, adhering to basic ethical principles, and should not accept gifts from client companies in any way, the auditor should remain vigilant regarding any incentives or gifts that are prohibited by law in many countries. An auditor's acceptance of an incentive or gift constitutes unethical behavior and violates the principle of honesty. Unwavering attention must be paid to the nature, frequency, value, cultural impact, and transparency of any incentive offered, including the assessment of the audit client's behavior using professional judgment. If it is determined that the incentive negatively affects behavior, measures must be taken, such as informing the company or customer business management and terminating the business relationship.

Keywords: Gift, Auditor, Spiral of Independence

Başvuru/Submitted: 10.03.2021 Revizyon Talebi/Revision Requested: 03.04.2021 Son Revizyon/Last Revision Received: 26.04 .2021 Kabul/Accepted: 30.04 .2021 Sorumlu yazar/Corresponding author: Süleyman Yükçü / suleyman.yukcu@deu.edu.tr

Atıf/Citation: Yukcu, S. ve Anli, S. (2021). Hediye, denetçi, bağımsızlık sarmal1. Muhasebe Enstitüsü Dergisi - Journal of Accounting Institute, 65, 1-12. https://doi.org/10.26650/MED.894559 


\section{Extended Abstract}

The main purpose of business is to maximize value within the boundaries of the resources they possess, and the main goal of investors is to leverage savings in areas that will bring maximum revenue. It is of utmost importance for businesses and investors to be able to rely on accurate financial information when making investment decisions to achieve their goals. Supervision is very important to the general national economy, business leaders, and third parties working with a business. Such decisions are often made referring to regular audits, as planning based on specified criteria and real indicators is more effective and accurate than strategies determined according to general economic development expectations. An independent audit refers to the objective examination of financial statements' compliance by an autonomous individual using generally accepted accounting standards to assess their accuracy and reliability. The independent auditor must act in accordance with the principles of professional ethics in the process of performing audits. In this context, the professional ethical principles with which independent auditors must comply include honesty, impartiality, professional behavior, confidentiality, professional competence, and care. In the scope of the principle of impartiality, the auditor's self-interest, a close relationship with clients, efforts of clients to get an auditor to adopt their own views, and other potentially compromising situations can affect impartial decision making. In such cases, the auditor performs professional activity in violation of the principles of professional ethics and the principle of impartiality. A circumstance that can cause such situations is that of gift-giving. Gifts can differ in many ways. Various aspects include whether the gift is tangible, the meaning it carries for the parties, and the purpose of the gift. In terms of tactility, gifts can be examined in two ways as tangible or abstract gifts. Examples of tangible gifts are assets such as goods and money. Abstract gifts can include lunches, cinema, concerts, sports activities, and other forms of entertainment. Giving gifts can build social relationships and strengthen existing relationships. Giftgiving is the selection, transfer, and evaluation of goods, services, and experiences as a spontaneous gesture or to fulfill an obligation. If gift-giving is considered from the perspective of the auditor, gifts received by the auditor may represent utilitarianism. When a gift is given, the other party may expect benefits. Such expectations include "positive opinion" or "high or low wages." This study explains the concept of gifts and the context of gift-giving is evaluated within the scope of auditors and independent audits. Within the framework of ethics, the issue of gift-giving is examined referencing preexisting data in the literature. According to the data obtained, hospitality offers, meal offers, or acceptance of gifts from an audit client to an independent auditor may result in self-interest or familiarity threats. As auditors must perform audits independently, adhering to basic ethical principles, and should not accept gifts from client companies in any way, the auditor should remain vigilant regarding any incentives or gifts that are prohibited by law in many countries. An auditor's acceptance of incentives or gifts constitutes unethical behavior and violates the principle of honesty. Unwavering attention must be paid to the nature, frequency, value, cultural impact, and transparency of any incentive offered, including assessment of the audit client's behavior using professional judgment. If it is determined that the incentive negatively affects the behavior, measures must be taken, such as informing the company or customer business management and terminating the business relationship. According to Article 200.7 of the Code of Ethics Standard for Independent Auditors, such internal notification is imperative when "the auditor receives gifts from the customer or receives privileged treatment unless it is of small or insignificant value." Regarding situations that pose a threat of proximity to the auditor "by a customer; A gift and entertainment offer may be presented to the auditor or to a member of the nuclear family or to one of their relatives. In this way, a proposal can create threats that hinder compliance with the fundamental principles" (Article 260.1). It is unquestionable that, in all cases, such gift-giving poses a threat and damages the principle of independence; therefore, any gifts or favors extended by companies to auditors within the framework of ethical rules should not be accepted. Ethical behavior should be exercised at all times, as it may harm the work performed and affect other related individuals groups. It is irrefutable that parties will be adversely affected by the presence of any form of gift-giving and receiving during an independent audit, in addition to suffering a damaged reputation if and when such indiscretions are reported. 


\section{Giriş}

İşletmelerin temel amacı, sahip oldukları kıt kaynaklar ile işletme değerini maksimize etmek, yatırımcıların temel amacı ise birikimlerini maksimum kar getirecek alanlarda kullanmaktır. İşletmelerin ve yatırımcıların amaçlarına ulaşmaları için yatırım kararlarını verirken finansal bilgilere güvenmeleri büyük önem arz etmektedir. Bunun yanı sıra finansal bilgiler, faaliyetlerin başarı düzeyini ölçmek için önemli bir araç olarak kabul edilmektedir. Yatırımcılar ve diğer ilgi grupları, işletmenin varlıklarının nasıl kullanıldığını ve karlı ve istikrarlı alanlara özgü olup olmadıklarını analiz ederken bu bilgilere güvenirler. Bu bakımdan denetim sistemi, yukarıda belirtilen ilgililere, kullanacakları bilgilerin doğru ve geçerli olduğuna dair güvence sağlar (Selimoğlu vd., 2009).

Denetim, genel ulusal ekonomi, yöneticiler ve işletme ile ilgilenen üçüncü şahıslar için oldukça önemlidir. Düzenli denetimler sonucunda alınan kararlar, ölçüt ve göstergelere dayalı olarak yapılan planlar, genel ekonomik gelişme beklentilerine göre yapılan planlara göre daha etkili ve isabetlidir.

Bağımsız denetim, finansal tabloların genel kabul görmüş muhasebe standartlarına uygunluğunun, doğruluğunun ve güvenilirliğinin bağımsız bir şekilde denetiminin yapılmasıdır (Yavaşoğlu, 2001). Bağımsız denetçi, muhasebe bilgilerinin doğruluğunu değerlendirirken genel kabul görmüş muhasebe ilkelerini kullanır. Bu nedenle söz konusu ilkeler konusunda eğitim alması ve bunu denetim faaliyetinde uygulaması gerekmektedir. Aynı zamanda denetçi, tarafsız olmanın yanı sıra kanıt toplama ve değerlendirme konusunda deneyimli ve uzman olmalıdır (Kepekçi, 2000).

Bağımsız denetim, tek bir kişi veya kurum için değil, tüm toplum için önemli bir kavramdır. Denetimi yürüten bağımsız denetçi, başta devlet olmak üzere tüm toplumun ve bilgi kullanıcılarının yararını gözetmek zorundadır. Bu nedenle denetim mesleğini icra ederken mesleki etik ilkelerine uygun hareket etmelidir. Bu bağlamda, bağımsız denetçilerin uyması gereken mesleki etik ilkeleri; dürüstlük, tarafsızlık, mesleğe uygun davranış, sır saklama ve mesleki yeterlilik ve özendir (KGK, 2014). Tarafsızlık ilkesi kapsamında denetçinin; kişisel çıkarlar, müşterilerle yakın ilişki, müşterilerin denetçinin kendi görüşlerini benimsemesini sağlama çabaları vb. durumlar tarafsız karar vermeyi etkileyebilir. Bu tür durumlarda denetçi, mesleki faaliyetini mesleki etik ilkelerine ve tarafsızlı ilkesine aykırı olarak gerçekleştirir. Bu duruma sebep olabilecek olaylardan biri de hediye alışverişidir.

Hediye vermek, sosyal ilişkileri kuran ve mevcut ilişkileri güçlendiren bir olaydır. Hediye vermek, kendiliğinden bir jest yapmak veya bir yükümlülüğü yerine getirmek için mal, hizmet ve deneyimlerin seçimi, transferi ve değerlendirilmesidir. Hediye verme bağımsız denetçi açısından değerlendirilecek olursa, denetçinin aldığı veya verdiği hediyeler faydacılığa girebilir. Hediye verildiğinde karşı taraf fayda beklentisi içine girebilir. Bu beklenti "olumlu görüş", "yüksek veya düşük ücret” vb. şeklinde olabilir.

Bağımsız denetçi, yalnızca denetlediği işletmeye karşı sorumlu değildir. Denetçi, bir tür kamu hizmeti sağlayan ve kamu yararına hizmet edecek biçimde davranma sorumluluğu bulunan mesleğin bir üyesidir. Bu nedenle mesleğini olması gerektiği şekilde icra etmeli ve bu yükümlülüğü yerine getirebilmek adına etik kurallara uygun bir biçimde hareket etmelidir. Çünkü bağımsız denetim hizmeti kullanıcıları, bu hizmetlerin sağlanmasında mesleki etik kuralların var olduğuna dair bir güven duygusu hissetmelidir (Keskin, 2016). Yapılan çalışmada, ilk olarak hediye kavramı açıklanacak olup sonrasında denetçiler ve bağımsız denetim kapsamında hediye kavramı değerlendirilecektir. Bu bağlamda etik konusu çerçevesinde mevcut konu, literatürde yer alan veriler doğrultusunda incelenecektir.

Muhasebe çatısı altında yer alan mesleklerin (YMM, SMMM, Bağımsız Denetçilik vb.) icrasında olduğu kadar birçok diğer mesleğin icrasında da hediye olgusu gerçek bir etik ikilem olarak karşımıza çıkmaktadır. Öğretmenlere öğretmenler gününde cumhuriyet altını hediye edilmesi, genel cerraha ameliyat sonrası el emeği adı altında para, baklava, yöresel ürünler hediye edilmesi, spor karşılaşmalarını yöneten hakemlere hediye verilmesi, politikacıya, bürokrata, yargı mensubuna hediye verilmesinin düşünülmesi, verilmesi, kabulü veya reddi başlı başına bağımsızlık sorunsalıdır. Hediye sadece muhasebe mesleğinin icrası konusunda değil, diğer tüm meslek ve ilişkilerde bağımsızlık sorunsalı olarak irdelenebilir. Hediye algısındaki yanlışlık tüm ilişkilere katlanarak yansıyabilir. 
Meslek mensuplarının bazıları en katı, mutlak haliyle hediyeye hayır derken, bir kısmı da bir işletmeye bir yıl hizmet verdikten sonra masum bir hediye teklif edilmemiş olmasını çok büyük bir kabalık olarak algılayabilmektedir. Makalenin ana amaçlarından bir tanesi de hediye olgusunun okuyucunun zihninde doğru parametreler ile oluşmasını sağlamaktır.

\section{Bağımsız Denetim ve Bağımsız Denetçi Kavramı}

Planlama, organize etme ve yürütme ile birlikte yönetimin temel işlevlerinden biri olan denetim, belirlenen kriterler ile elde edilen bilgiler arasındaki uygunluk derecesinin belirlenmesi ve raporlanması için iddialara ilişkin delillerin toplanması ve değerlendirilmesidir. Denetim, ekonomik, yasal ve etik sonuçları içeren ve aynı zamanda uzmanlık gerektiren bir görevdir (Saxena vd., 2010).

Denetim işini meslek olarak icra eden kişiye denetçi denir. Denetçi, standart davranışlar olarak nitelendirilmen temel ilkelere tümüyle uyumlu çalışmalıdır. Söz konusu temel ilkeler; dürüstlük, tarafsızlık, mesleki yeterlilik ve özen, sır saklama ve mesleğe uygun davranış olarak belirlenmiştir (Bağımsız Denetçiler İçin Etik Kurallar 110.1 U1). Denetçi, mesleğini yerine getirirken temel ilkeleri dikkate almalı ve bu ilkelere uyumu engelleyecek tehditleri belirlemek ve değerlendirmek için kavramsal çerçeveyi uygulamalı ve tehditleri değerlendirirken müşterinin faaliyet gösterdiği ortamı dikkate almalıdır. Denetim firması için bu süreçte temel ilkelere uygun liderlik yapısı, ücret ve performans değerlendirme, mesleki eğitim ve kullanılacak şikâyet mekanizmaları önemlidir. Bu tehditlerin yeniden değerlendirilmesi için yeni bilgi, durum ve değişikliklerin (işletmelerin birleşmesi, şirket hisse senetlerinin borsada alım satımı, hizmet kapsamının genişletilmesi vb.) gerçekleşmesi ile denetçi tarafından kavramsal çerçevenin uygulanması gereklidir (Yazar, 2021).

Denetim amaçlarına, uygulanma zamanına ve denetçi türlerine göre sınıflandırılabilmektedir. Denetçi türlerine göre denetim; iç denetim, kamu denetimi ve bağımsız denetim olmak üzere üçe ayrılmaktadır. İç denetim, işletmede sürekli çalışan veya sürekli olarak şirket dışında iç denetçi olarak çalışanların finansal ve finansal olmayan bütün işletme faaliyetlerinin incelenmesidir. Diğer bir ifadeyle, kamu ya da özel sektörde ücret sözleşmesi ile hizmet veren kişilerin yönetim adına yaptı̆̆ı bir denetim türüdür (Kavut vd., 2009:). Kamu denetimi ise, kamu idarelerinde istihdam edilen ve kamu yararı gözetilerek çalışanlar tarafından yapılan denetimlere denir. Kamu denetimi, kamu kurum ve kuruluşları ile özel sektör işletmelerinin devlet tarafından yetkilendirilmiş denetçiler tarafından incelenmesidir (Kavut vd., 2009). Kamu denetiminde yasal otorite tarafından belirlenen prosedürlere uyulup uyulmadığı kontrol edilir (Selimoğlu vd., 2012). Bağımsız denetim ise kurulca talep edilecek ya da işletmelerin halka açıklanacak yıllık finansal tablolarının ve diğer finansal bilgilerinin uygunluğu ve doğruluğu konusunda makul güvence sağlayacak yeterli ve uygun bağımsız denetim kanıtı elde etmek amacıyla, bağımsız denetim standartlarında öngörülen gerekli tüm bağımsız denetim teknikleri kullanılarak kayıt, defter ve belgeler üzerinden denetlenmesi ve değerlendirilerek raporlanmasıdır (SPK, 2006). Bağımsız denetim şirket ile iş̧̧i-işveren ilişkisi içinde olmayan kişiler tarafından yapıldığından, bu denetim türü aynı zamanda dış denetim olarak da tanımlanmaktadır (Eroğlu, 2010).

KGK tarafından bağımsız denetim yapmak üzere yetkilendirilen Yeminli Mali Müşavir (YMM) ya da Serbest Muhasebeci Mali Müşavir (SMMM) ruhsatını almış meslek mensupları ile birlikte ortakları YMM ve SMMM olan ve KGK tarafından bağımsız denetim yapmak üzere yetkilendirilen sermaye şirketleri bağımsız denetim kuruluşlarıdır (Yükçü ve Alkan, 2020).

Bağımsız denetçi ise denetimi faaliyet alanı olarak gören ve bağımsız olarak veya bir denetim firmasına bağlı olarak çalışan denetçilerdir. Bu denetçiler, işletmelerin mevcut durumu hakkında bilgi almak isteyen kişi veya kuruluşların talepleri doğrultusunda denetim faaliyetlerini yürütürler (Bakır, 2003). Diğer bir deyişle bağımsız denetçiler, bir denetim şirketinde çalışan, müşsterilerine profesyonel bir denetim hizmeti sunan uzmanlardır. Bă̆ımsız denetçiler, eğitimleri, deneyimleri ve nitelikleri ile çeşitli denetim işlevlerini en iyi şekilde yerine getirebilen profesyonellerdir (Güredin, 2000).

\section{Hediye Kavramı}

The American Heritage Dictionary'e (2016) göre hediye; "gönüllü olarak verilen ve parasal geri dönüşü olmayan bir şey" olarak tanımlanmıştır. Başka bir tanıma göre hediye; ritüeller ve törenler yoluyla bir kişiye veya gruba gönüllü olarak mal 
ve hizmet sağlamaktır. Türkçe'de eş anlamlı olarak "armağan" kelimesi de kullanılmaktadır. Bir mal veya hizmetin hediye olma koşulu, zorunluluk veya yasal yaptırım dışında ve gönüllü olarak verilmesidir. Ayrıca bir mal veya hizmetin hediye olmasının ön koşulu, hediye verme ve alma sürecinde tören ve ritüellerin olmasıdır (Köse, 2017).

İnsanlar arasındaki bağl1lığı kuvvetlendiren ve yardımlaşmayı sağlayan hediye, bayram, düğün, doğum günü, yeni ev ziyareti, yeni iş gibi özel günlerde verilebileceği gibi herhangi bir zaman da verilebilir. Asırlar boyunca toplumların din, adet, gelenek ve göreneklerine göre çeşitli eşyalar hediye olarak verilmiş̧ir.

Hediye bir kavram olarak ilk kez Mauss (1950) tarafından incelenmiştir. Mauss (1950) yaptığı çalışmada arkaik ve ilkel toplumlarda hediye verme davranışlarını ele almıştır. İlkel toplumların sosyal ve ekonomik yaşamını şekillendiren hediyelerin özelliklerini ayrıntılı olarak değerlendirmiştir. Zaman içerisinde hediye kavramı ile ilgili farklı disiplinlerde çalışmalar yapılmıştır. Her disiplin, hediye kavramının ilgili boyutu ile ilgili tanımlamalar yapmaya önem vermiştir. Sosyal bilimler alanyazınında pek çok alanda hediye kavramı üzerine tartışmalar söz konusu olmuştur (Köse, 2017).

Hayatımızda hediyenin yeri ne kadar duygusal olsa da olmazsa olmaz haline gelmiştir. Hediye veren kişi, karşısındaki kişiyi mutlu etmek, memnun etmek veya bir işini gördürmek için hediye ve hediye yerine geçen ürünleri verme isteği duyuyor. Hediye alan kişi öncelikle mutlu oluyor, çalışma isteği ile motivasyonu artıyor, kendine güveni geliyor, etrafa pozitif enerji yayıyor. Bazen içimizden gelerek yapılan bir hareket olsa da aslında asıll amaç iş hayatında iş gördürme, özel hayatta gönül almak için diye sıralayabiliriz.

Hediye verilmesinin amaçları aşă̆ıdaki gibi maddelendirebiliriz;

- Müşteri edinmek,

- İşilişkilerini güçlendirmek,

- Karşı tarafı mutlu etmek,

- Çalışanları motive etmek,

- Daha başarılı olunması için teşvik etmek,

- İşletmeye bağlılıkları arttırmak,

- Alıcı - Satıcı arasındaki bağı güçlendirmek,

- Yeni iş almak, mevcut işi sürdürmek veya uygun olmayan başka çıkarları temin etmek vb. (Dünya Çapında Hediye Verme ve Ağırlama Kuralları, 2013).

\subsection{Hediye Çeşitleri}

Hediyeler birçok yönden farklılık gösterebilir. Bu farklılıklar, hediyenin somut olup olmadığı, taraflar için taşıdığı anlam ve hediyenin amacı gibi çeşitli açılardan olabilmektedir. Dokunsallık açısından hediyeler somut hediyeler ve soyut hediyeler olarak iki şekilde incelenebilir. Somut hediyelere örnek olarak her türlü eşya ve para gibi varlıklar verilebilir. Soyut hediyeler ise öğlen yemeği, sinema, konser, sporsal faaliyetler, eğlence olarak örneklendirilebilir (Köksalan, 2019).

Öte yandan hediyeler, hediye verme amacına bağlı olarak hediye; kişisel hediyeler, promosyonlar ve bağışlar olarak üç kategoriye ayrılır. Kişisel hediyelerde duygularımızı ifade etme amacı ön plana çıkmaktadır. Promosyon amaçlı hediyelerde taraflar arasında iş ilişkisi kurulması ve mevcut iş ilişkilerinin güçlendirilmesi amaçlanır. Bağışlarda ise toplumun ihtiyaç duyduğu bir noktada topluma fayda sağlama amacı ön plana çıkmaktadır. Bağış türü hediyelerde toplumda ihtiyaç sahibi kesimlere maddi ve manevi bir destek sağlama söz konusu olmaktadır. (Köksalan, 2019).

Öncelikle hediye alacağımız kişinin birçok özelliği gözden geçirilmelidir. Örneğin; bir düğün hediyesi için sofra takımı, mutfak aletleri, yeni doğmuş bir bebeğe hediye alınacaksa da bir buket çiçek, çikolata, altın veya giyim kategorileri 
seçilebilir. Yine değerli bir takı, kravat, gömlek, çakmak, cüzdan, kemer, parfüm, kupa, kol saati, kolye, künye, küpe, bluz, çiçek, ayakkabı vb. gibi ürünlerin yanı sıra villa, konut, otomobil, motosiklet, yemek yeme, tatil için uçak bileti de hediye olarak tercih edilebilecekler arasındadır. Bunlara ek olarak hediye seçimi yapılırken yaş, cinsiyet ve yakınlık derecesi de göz önünde bulundurulmalıdır.

\subsection{Hediye Verme Nedenleri ve Güdüleri}

Mutlu etmek, küs olduğumuz kişilerle barışmak, tebrik ve kutlama, sevgimizi gösterebilmek, motive etmek, hayırlı olsun ziyaretleri, yapılmasını istediğimiz bir işlemin çabuk olması, bir karar neticesinde lehimize karar verilmesi, iş görme / gördürme gibi vb. nedenlerle hediye verilebilmektedir (Şeker, 2019).

Hediye, karşımızdaki kişiye değer verdiğimizi göstermek içindir. Sevdiklerimize, eşimize, arkadaşlarımıza, dostumuza, akrabalarımıza özel günlerinde veya bayram, yeni yıl gibi herkes için anlam taşıyan zamanlarda, onların zevkleri ve ihtiyaçları doğrultusunda bir şeyler alırız. Onlarda aynı şekilde bizlere hediye verirler.

Bilhassa belli özel günlerde hediye vermek, modern toplumda yer alan tüm bireyler tarafindan oldukça sıklıkla gerçekleştirilen bir durumdur. Sevgililer günü, yılbaşı, anneler günü, babalar günü, evlilik yıl dönümü gibi günlerde hediye alma davranışı gerçekleştirilebilmektedir. Bunun yanı sıra inanca göre hediye alımı da söz konusu olabilmektedir. Örneğin, yılbaşı, dini bayramlar gibi inanç açısında önem arz eden günlerde de bireyler birbirlerine hediye alabilmektedirler.

Güdüler, bir kişinin davranışını 'uyandıran' ve 'yönlendiren' bir iç faktör olarak tanımlanır. Hediye verme nedenleri, hediyeyi verenin alıcının memnuniyetini en üst düzeye çıkarmaya çalıştığı "fedakârlıktan ", kendi memnuniyetini en üst düzeye çıkarmaya çalıştığı "ego" ya değin değişim göstermektedir. Başka bir deyişle, hediyeler motivasyonel bir süreklilik içinde özgecilik ve ego kutupları arasındaki birden fazla nedenden kaynaklanabilir. Buradaki amaç; tarafların asgari memnuniyet elde etmek veya maksimum düzeyde memnuniyetsizlikten kaçınmak arzusudur. Hediye verme konusunda alanyazında yer alan güdüler aşağıda sıralanmaktadır (Köse, 2017);

- Fedakârlık

- Prestij

- Sosyalleşmek

- Ritüelleri korumak

- Özür dilemek

- Faydac1lı

- Karşıllkl11lk

- Ego

Yukarıdaki güdülerle verilen hediye kırdan toplanmış maliyeti sıfır olan çiçek olabileceği gibi emsal bedeli milyonlarca lirayla ifade edebilecek villada olabilir.

\section{Bağımsız Denetim ve Hediye Bağlamı}

Bağımsızlık, denetçinin doğruluk ve dürüstlüğün bir yadsımasıdır (Atağan, 2007). Kamuoyu aydınlatma sorumluluğu taşıyan denetçinin her iki tarafı da memnun etme gibi bir yükümlülüğü olamaz. Çünkü bağımsızlık ve etik gereği, mali tablolar konusunda gerçek ne ise denetçi onu aynen yansıtmalıdır (Başkan, 2013).

Müşteriye bağımsızlığı sağlamak amacıyla denetim kuruluşunun iş teklifi edemeyeceği ancak kendisine yapılan teklifleri değerlendirip kabul edip etmeyeceği konusunda karar vereceği düzenlenmiştir. Denetçinin denetlediği işin sahibi ile kişisel 
ilişkisi ve samimiyet derecesi tarafsızlığın bozulmasında etkili bir unsurdur. Böyle durumlarda denetçilerin ilişkileri göz önüne alarak değerlendirme yapma olasılı̆̆ı söz konusudur ki bu da bağımsız denetçilerin, yönetim baskılarına dayanma gücünü olumsuz etkilemektedir (Ulucan ve Özdemir, 2014).

Denetçinin, görünüşte bağımsız olması gerektiği gibi fikren de bağımsız olması gerekir (Gümrah, 2017). Uluslararası bağımsız dış denetim firmaları personeli ve ortakları için müşterilerine karşı bağımsızlıklarını koruyabilmek için katı kurallar koymuşlardır. Bu kuralların başında hediye alınmasını engelleyen düzenlemeler gelmektedir. Denetçilere tarafsız incelemenin nasıl yapılacağı, prensipler ve müşteriye nasıl taviz verilmeyeceği konularında uygulamalı çalışmalar yapılmaktadır. Böylece bağımsızlığın sadece bir dizi kuraldan ibaret olmadığı, fakat mesleki bir davranış olduğu vurgulanmaktadır (Kahyaoğlu, 2017).

Resmî Gazete'de yayınlanan Bağımsız denetçiler için etik kurallar standartları içerisinde hediye bağlamında çeşitli maddeler yer almaktadır. 30.11.2017 tarihli 30256(M) sayılı Resmî Gazete'de yayınlanan Bağımsız denetçiler için etik kurallar standardının 200.7 maddesine göre "denetçi için yakınlı tehdidi oluşturan durumlara ilişskin "denetçinin, küçük veya önemsiz bir değerde olmadı̆̆g sürece müşteriden hediye alması veya ayrıcalıkl muamele görmesi”, 260.1 maddesine göre "bir müşteri tarafindan; deneţ̧iye veya çekirdek ailesinin üyesine veya yakınlarından birine hediye ve ağırlanma teklifi sunulabilir. Bu şekilde bir teklif, temel ilkelere uyumu engelleyen tehditler oluşturabilir.” Örneğin, bir müşteriden hediye alınması tarafsızlığa yönelik bir kişisel çıkar veya yakınlık tehdidi oluşturabilir. Bu tekliflerin kamuya duyurulması ihtimali nedeniyle tarafsızlığa yönelik bir yıldırma tehdidi oluşturabilir.

Etik kuralların 260.2 maddesine göre, "herhangi bir tehdidin varllğl ve ciddiyeti; teklifin niteliğine, değerine ve amacına bağlldır. Gerekli bilgiye sahip makul üçüncü bir tarafin -mevcut tüm özel durum ve gereçleri değerlendirmek suretiyle küçük ve önemsiz kabul edeceği bir hediye veya ağırlanma teklifi sunulması durumunda denetçi, söz konusu teklifin karar alma veya bilgi edinme sürecini etkilemeye yönelik özel bir amaç olmaksızın işlerin normal akışında yapıldiğı sonucuna varabilir. Bu tür durumlarda denetçi, genellikle temel ilkelere uyuma yönelik tehdidin kabul edilebilir bir düzeyde olduğu sonucuna varabilir." Örneğin; küçük ve önemsiz bir düzeyde hediye alan denetçi, denetim yapılan firmayla ilgili raporunda temel ilkelere bağlı kalmayıp, bir olayı göz ardı edip olumlu rapor verebilir buda her ne kadar denetim yapılan firma için olumlu bir karar olsa da üçüncü kişilerin zarar görmesine sebep olabilir.

Etik kuralların 260.3 maddesine göre, "denetçi, her türlü tehdidin ciddiyetini değerlendirir ve gerektiğinde bunları ortadan kaldırmak veya kabul edilebilir bir düzeye indirmek için önlemler alır. Tehditlerin ortadan kaldırılamaması veya kabul edilebilir bir düzeye indirilememesi durumunda denetçi, böyle bir teklifi kabul etmez."

Denetçi bağımsız ve temel etik ilkelere bağlı kalarak bir şirketi denetlemesi gerekli olup, şirket tarafından hiçbir şekilde hediye kabul etmemelidir. Denetim şirketlerinin veya kilit yöneticilerinin veya çalışanın ya da bu kişilerin çekirdek aileden üyelerinden birisine hediye veya miras gibi yollarla denetlenen şirketten doğrudan önemli düzeyde finansal çıkar elde edilmesi durumunda söz konusu çıkarın elde tutulmasına izin verilmez (Bağımsız Denetçiler için Etik Kurallar, A510.9).

Denetim müşterisinden denetim personeline ağırlanma teklifi, yemek yeme teklifi veya hediyelerin kabul edilmesi kişisel çıkar veya yakınlık tehdidi oluşturabilir. Faaliyetlere etki edebilecek veya etki etmesi beklenebilecek düzeyde herhangi bir hediye iltifat veya misafirperverlik kabul edilmemelidir.

Etik değerleri algılama ve uygulamada çevre etkisine baktığımızda, işlerimizi kolaylaştırmak için hediye almak ya da vermek gereklidir. Denetçilerin müşterilerden mesleki etik, ahlak ve yasal sınırlar içinde hediye kabul etmesinin duygusal zekâ seviyeleri ile anlamlı farklılar olduğu saptanmıştır. Bu sonuca göre duygusal zekanın yüksekliği ile denetçilerin hediye, rüşvet, eşantiyon gibi eşya veya ürünleri ya da hizmetleri bağımsızlıklarının tehlikeye düşmesi önlenebilir.

\subsection{Bağımsız Denetçi ve Hediye Bağlamı}

Teşvik, başka bir bireyin davranışını etkilemek için bir araç olarak kullanılan, ancak tam olarak da kişinin davranışını uygunsuz bir şekilde etkileme niyetiyle kullanılmayan bir nesne, durum veya eylemdir (Bağımsız Denetçiler için Etik 
Kurallar, 340.4 U1). Bu durum, küçük eğlencelerden yasal düzenlemelere aykırı davranışlara kadar geniş bir kapsama sahiptir. Bu nedenle, denetlenen kurum, denetçinin etik ilke ve kurallara aykırı hareket edebileceği hediyeler ve ağırlamalar dahil olmak üzere denetçiye teşvikler sunmamalıdır. Bu, denetçinin bağımsızlığı için bir tehdit oluşturabilir (Dal ve Çalış, 2013).

Denetçi, birçok ülkede kanunla yasaklanmış olan teşviklere ve hediyelere dikkat etmelidir. Çünkü denetçinin etik olmayan davranışa neden olan bir teşviki veya hediyeyi kabul etmesi veya sunması dürüstlük ilkesini ihlal eder. Bu bağlamda, teşvikin niteliğine, sıklığına, değerine, kültürel etkisine, şeffaflığına ve denetim müşterisinin bu tür davranışları mesleki muhakemeyle değerlendirmesine dikkat edilmelidir. Teşvikin davranışı olumsuz etkilediği tespit edilirse, firma veya müşteri iş yönetimini bilgilendirmek ve iş ilişkisini sonlandırmak gibi önlemler alınmalıdır (Dal ve Çalış, 2013).

Bir denetim müşterisinin, denetçinin aile üyelerine veya denetçinin aile üyelerinin müşteriye teşvik (iş, hediye vs.) teklif etmesi etik bir tehdit oluşturur. Bu kapsamda teşvikin reddedilmesi, hayır kurumlarına devredilmesi, teşvik verilmemesi, profesyonel hizmet sorumluluğunun tekliften etkilenmeyen kişiye devredilmesi ve konu hakkında üst yönetime bilgi verilmesi gibi adımlar atılabilir (Yazar, 2021).

Kişinin davranışını uygunsuz bir şekilde etkilemeyi amaçlamayan küçük ve önemsiz teşvikler kabul edilebilir düzeylerde olmalıdır. Örneğin; başka bir müşteri tarafından kurumsal finansman hizmeti verilen bir işletmenin satın alınması sürecinde denetçiye ev sahipliği yapılması, müşteri işletme müdürü ile birlikte denetçinin spor faaliyetlerine katılması vb. (Yazar, 2021) durumlar kabul edilebilir düzeydedir.

Aşağıda yer alan konular bağımsız denetçinin bağımsızlığını bozmaktadır;

- Denetlediği işletmenin ortağı olması

- Denetlenen işletmenin sahipleriyle ortaklık ilişkisinde bulunması

- Denetlenen işletmeden maaş alması, borç vb. ilişkisinin olması

- Denetlenen işletmeye ait hisse senedi, tahvil veya benzeri bir menkul kıymet yatırımı yapmış olması

- Denetlenen işletmenin ortakları veya yöneticileri ile kan bağının olması

- Denetlenen işletme ile ticari bir ilişkisinin olması

- Denetlenen şirketten önemli sayılabilecek tutarda hediye alınması

- Denetlenen işletmeden çok özel indirimle bir varlık veya fayda alınması (Müslümov ve Aras, 2002).

\subsection{Bağımsız Denetim ve Hediye ile İlgili Senaryolar}

Bağımsız denetim kapsamında hediye alıp vermenin etik boyutunun değerlendirebilmesi için örnek olaylar üzerinde çeşitli senaryolar oluşturulmuş ve değerlendirilmiştir.

- Faruk, bazı yapı projelerindeki aktifleştirilmiş finansman gideri ile ilgili yapılan işlemde müşteri ile aynı fikirde olmadığını denetim müdürüne iletmiştir. Denetim müdürü ise, Faruk’un teknik olarak doğru olma ihtimaline rağmen, çocuklarının okuduğu kolejin ortaklarından olan ve denetim müdürüne indirim yapılmasını sağlayan müşterinin pozisyonunun makul bir şekilde desteklenebileceğini belirterek müşterinin tarafında olmuştur. Faruk, çalışma kağıtlarını, işlemin GKGMİ (Genel Kabul Görmüş Muhasebe İlkeleri) ile uyumlu olduğunu ifade edecek şekilde değiştirmiştir.

Verilen örnek senaryoda, hediye olarak kolejde okuyan çocuklara yönelik indirim yapılması söz konusudur. Denetim firmasının bir çalışanı olan Faruk ise işsiz kalma ve maddi problem yaşama kaygısı ile çalışma kağıtlarında değişikliğe gitmiştir. Verilen örnekte hediyenin bağımsız denetimin işleyişinde yarattığı olumsuz etki açıkça görülmektedir. 
- X Pazarlama A.Ş. Pazarlama Müdürü, şirket yemekhanesinde şirketin bağımsız denetçileri ile karşılaşmıştır. Şirketin bağımsız denetçileri pazarlama müdürünü öğle yemeğini birlikte yemek için masalarına davet etmişlerdir. Pazarlama müdürü daveti memnuniyetle kabul etmiş ve bağımsız denetçilerin gelecek hafta yıllık izne çıkacaklarını öğrenmiştir. Kendisinin Bodrum'da uzun süredir kullanmadığı için boş olan yazlığından bahsederek isterlerse kullanabileceklerini bağımsız denetçilere teklif etmiştir. Bu teklif, henüz bir plan yapmamış olan bağımsız denetçilere cazip gelmiş ve teşekkür ederek teklifi kabul etmişlerdir. Yemek sonunda pazarlama müdürü yazlık evinin adresini ve anahtarını almaları için odasına uğramalarını rica ederek bağımsız denetçilerden izin isteyerek yanlarından ayrılmıştır.

Verilen senaryoda, hediye olarak yazlık evin kullanımı söz konusudur. Yazlık evin kullanım teklifinin kabul edilmesi neticesinde, ilerleyen dönemlerde şirket bünyesinde karşılaşlabilecek olumsuz bir durumda bağımsız denetçilerin tarafsızlıklarını ne derece koruyabilecekleri belirsizdir. Bu durum denetçilerin 'bağımsız'lığını olumsuz yönde etkileyebilecektir.

- İşletme yöneticisi, denetçiye, kendi kardeşinin çalışmakta olduğu özel bir araba firmasının servisinde aracının yıllık bakımını ücretsiz bir şekilde yaptırabileceğini ifade etmiş ve bunu iş dışında arkadaşlıklarının bir göstergesi olarak kabul etmesini istemiştir. Denetçi, arkadaşça gördüğü teklifi kabul etmiş ve aracının bakımını ücretsiz olarak yaptırmıştır. Şirketin finansal denetimi sonucunda ise denetçi, işletmenin faaliyet sonuçlarını önemli derecede şişirdiğini fark etmiştir. Faaliyet sonuçlarının uygun bir şekilde yeniden beyan edilmesi durumunda yöneticinin ikramiyesi önemli derecede azalacaktır. Denetçi; şirket muhasebecisine faaliyet sonuçlarını şişirmesini yöneticinin söylediğini öğrenmiştir. Denetçi, faaliyet sonuçlarının şişirilme nedenini rapor etmemiştir.

Verilen örnek senaryoda, hediye olarak ücretsiz araç bakımının yapılması söz konusudur. Ayrıca yönetici ve denetçi arasındaki arkadaşlık bağı da bağımsız denetçinin, mesleki etik ilkelere bağlılığını zedelemiş ve faaliyet sonuçlarının şişirilme nedenini rapor etmemiştir.

- Şekerleme ve çikolata üreten Şeker A.Ş., Kontrol A.Ş. bağımsız denetim şirketi tarafından bağımsız denetime tabi tutulmaktadır. Kontrol A.Ş.'nin toplam personel 20 kişi, Şeker A.Ş.'nin denetim ekibi ise 7 kişiden oluşmaktadır. Şeker A.Ş.'de toplam 250 kişi çalışmaktadır. Şeker A.Ş. kendi personeline yılbaşında ve dini bayramlarda olmak üzere toplam 3 kez çikolatadan oluşan hediye paketi ile hediye verip personelin şirkete aidiyet duygusunu arttırmaya çalışmaktadır.

Şeker A.Ş’’nin mali işler müdürünün, şirketin bağımsız denetim ekibine de aynı çikolata paketinin yılda 3 kez verilmesini önerdiği, yönetim kurulunun bunu onayladığı, hediyenin 7 kişiye teslim edildiği bildirilmiştir.

Konuyu öğrenen 7 kişilik denetim ekibinde bulunmayan Kontrol A.Ş.'nin yönetim kurulu başkanı konuya tepki göstermiş, bu yaklaşımın bağımsızlık olgusunu bozacağını hediyelerin iade edilmesini söylemiştir.

Hediye iadesi Şeker A.Ş. için kırıcı olacağından, bu defaya mahsus hediyelerin iade edilmemesi, ancak bundan sonra bu tür hediyelerin kabul edilmemesi kararı alınmıştır.

Şeker A.Ş.'nin bünyesinde bulunduğu holdingin Bodrum'daki otelinde Kontrol A.Ş. personelinin \%50 indirimli tatil yapıp yapamayacă̆ı holding yetkililerine sorulmuş, olumlu yanıt alınması durumunda Kontrol A.Ş.'nin personeli yaz aylarında parti parti birer hafta tatil yapacaklardır. (Yükçü ve Alkan, 2020).

Verilen senaryolarda şu sorular gündeme gelmektedir;

- İlk senaryodaki denetim müdürünün çocuklarını müşterisinin ortağı olduğu koleje göndermesi bağımsızlık ilkesini bozar mı?

- X Pazarlama A.Ş. Pazarlama Müdürünün, bağımsız denetçilere tatil için yazlığında kalmalarını teklif etmesi bağımsızlık ilkesini bozar mı? 
- Denetçinin, işletme yöneticisinin kardeşinin çalışmakta olduğu özel bir araba firmasının servisinde aracının yıllık bakımını ücretsiz bir şekilde yaptırması bağımsızlık ilkesini bozar mı?

- Şekerleme ve çikolata üreten işletmeden, bağımsız denetim ekibine çikolata hediyesi bağımsızlık ilkesini bozar mı?

- Hediye tüm Kontrol A.Ş. çalışanlarına verilseydi bağımsızlık ilkesini bozar mı?

- Şeker A.Ş.'nin kendi çalışanlarına -250 kişiye- çikolata hediye etmesi bağımsızlık ilkesini bozar mı?

- Şeker A.Ş.'nin bağlı bulunan vergi dairesi müdür ve müdür yardımcılarına, vergi iade bildirilerine bakan memura, şehrin valisine, belediye başkanına çikolata hediye etmesi bağımsızlık ilkesini bozar mı?

- Şeker A.Ş.'nin huzurevi sakinlerine bayram ziyareti ile çikolata hediye etmesi bağımsızlık ilkesini bozar mı?

- Kontrol A.Ş.'ye gönderilen 7 adet hediye paketinin iade edilmesi bağımsızlık ilkesini bozar mıydı?

- Şeker A.Ş.'den bundan böyle hediye kabul edilmemesi bağımsızlık ilkesini bozar mı?

- Kontrol A.Ş. personelinin Bodrum'daki otelde tatil yapması bağımsızlık ilkesini bozar mı?

- Dört senaryoda da söz konusu hediyeler tüm çalışanlara verilseydi bağımsızlık ilkesine bağlı kalınmış olur muydu?

- Bundan sonrasında hediye kabul edilmemesi bağımsızlık ilkesinin uygulanması için yeterli olur mu?

Ele alınan senaryolarda hediye olgusunun bağımsız denetimi gölgelediği, bağımsızlık ilkesine yönelik çeşitli soruları ortaya koyduğu ve sürecin temel etik ilkelere göre yürütülemediği görülmüştür. Bu durumda bağımsız denetçilerin hediye alıp verilmesi konusunda oldukça dikkatli olmaları gerektiği görülmektedir.

\section{Tartışma ve Sonuç}

Denetçiye hediye veren denetlenen şirketler, firmalarını denetlettikleri kişiler ile yakın olma yoluna giderek onlardan olumlu rapor vermelerini bekler. Eğer ki tersi yönünde rapor çıkmasından endişeli iseler, bunu olumluya çevirmek için hediye verme yoluna giderler. Denetçi kişi ya da kişileri tüm yönleri ile inceler ve beklentilerini olumlu yönde karşılayacak hediye vererek istedikleri sonuçtaki raporu alabilirler. Bağımsız denetim işinde çalışan kişi ya da kişiler ve bu kişilerin çekirdek aile üyelerinin ise hiçbir şekilde bağımsızlıklarını etkileyecek şekilde denetimini yaptıkları firmalardan parasal değeri bulunan hediyeler alma gibi bir beklenti içine girmemeleri gerekir.

Bağımsız denetim firmaları personellerini etik kurallara uymaları için uygulamalı eğitimlere alarak hediye beklentilerinin önüne geçmek adına çalışmalar yapmaya devam etmelidirler. Her ne kadar şirketler hediye verme duygusu içinde işlerinin karşılığını olumlu almak isteseler de bağımsız denetim personelleri etik kurallar çerçevesinde bağımsız davranarak bir karşılık beklememektedirler. Adı ne olursa olsun, parasal değeri olup denetimi yapılan şirket tarafından, denetim yapan personele verilen parasal değeri olan her türlü şey denetçinin bağımsızlı̆̆ını bozmaktadır.

Kızılboğa (2013) denetimin etkin ve etkili bir şekilde yürütülmesinde denetçilerin bağımsızlık ve tarafsızlığının etkisini ve önemini açıkladığı çalışmasında, incelenen olay veya süreç hakkında kişisel çıkar veya başkalarının görüşleri nedeniyle etki altında kalınmamasını vurgulamıştır.

Denetçiler müşterilerinden, satıcılardan ve kurumsal iş ilişkilerinde bulundukları kişi ve kuruluşlardan değerli herhangi bir şeyi veya hediyeyi kabul edemezler.

Erken (2009), denetimde bağımsızlık kavramını ele aldığı çalışmasında denetimlerin en başından sonuna kadar sıkı bir şekilde etik kurallara ve standartlara uygun olarak yürütülmesi gerekmektedir. Denetçinin yapmış olduğu tüm çalışmaların bu kurallar ve standartlar açısından gözden geçirilmesi gerektiğini ifade etmiştir. 
Yükçü ve Alkan (2020) "Senaryolarla Denetimde Etik" adlı kitaplarında denetim firmaları ve denetçilerin bağımsız kalma sorumluluğu olduğunu ifade etmişlerdir. Denetçi, bağımsızlığına yönelik tehditleri minimize etmek ya da ortadan kaldırmak için gerekli önlemleri almalıdır. Denetçi bağımsızlığına yönelik tehditler; kişisel menfaat tehditleri, kendi kendini denetleme tehditleri, savunma tehditleri, yakınlık veya güven tehditleri ve yıldırma tehditleridir. Denetçinin küçük ya da önemsiz bir değerde olmadığı sürece müşteriden hediye alması veya ayrıcalıklı muamele görmesi etik kurallarla belirtilen yakınlık tehdidi olarak ifade edilmektedir. Nitekim Bağımsız Denetçiler için Etik Kurallar'ın 420.2 maddesine göre "Denetim müşterisinin hediyesinin ve ağırlanma teklifinin kabul edilmesi, kişisel çıkar, yakınlık veya yıldırma tehdidi oluşturabilir." Dolayısıyla denetçi bağımsızlığını bozmaması amacıyla önemli bir değeri olan hediyeleri kabul etmekten kaçınmalıdır.

Hediyenin her ne olursa olsun bir tehdit oluşturacağı, bağımsızlık ilkesine zarar vereceği aşikardır. Bu yüzden de etik kurallar çerçevesinde denetçilerin denetimini yaptığı şirketlerden hediye vb. kabul etmemelidir. Yapılan çalışmaya zarar vereceği ve diğer ilişkili grupları etkileyebileceği için etik davranılmalıdır. Hediye alıp- verme bağımsız denetim işi yapılması esnasında, taraflar olumsuz bir şekilde etkileneceği gibi, duyulduğunda itibara zarar verebileceği de unutulmamalıdır.

Hakem Değerlendirmesi: Dış bağımsız.

Çıkar Çatışması: Yazarlar çıkar çatışması bildirmemiştir.

Yazar Katkıları: Çalışma Konsepti/Tasarım- S.A., S.Y.; Veri Toplama- S.A., S.Y.; Veri Analizi/Yorumlama- S.A., S.Y.; Yazı Taslağı- S.A., S.Y.; İçeriğin Eleştirel İncelemesi- S.A., S.Y.; Son Onay ve Sorumluluk- S.A., S.Y.

Finansal Destek: Yazarlar bu çalışma için finansal destek almadığını beyan etmiştir.

Peer-review: Externally peer-reviewed.

Conflict of Interest: The authors have no conflict of interest to declare.

Author Contributions: Conception/Design of Study- S.A., S.Y.; Data Acquisition- S.A., S.Y.; Data Analysis/Interpretation- S.A., S.Y.; Drafting Manuscript S.A., S.Y.; Critical Revision of Manuscript- S.A., S.Y.; Final Approval and Accountability- S.A., S.Y.

Grant Support: The authors declared that this study has received no financial support.

\section{Kaynaklar}

“Bağımsız Denetçiler İçin Etik Kurallar”, 30/11/2017 tarihli ve 30256(M) sayılı Resmî Gazete.

“Dünya Çapında Hediye Verme ve Ağırlama Kuralları” Last Revised: June 2013 https:/www.eaton.com/ecm/groups/public/@pub/@ eaton/@corp/documents/content/ct_251847.pdf

Atağan, H. (2007), Uluslararası gelişmeler çerçevesinde denetçinin bağımsızlı̆̆ı. (Yüksek Lisans Tezi). Dokuz Eylül Üniversitesi, Sosyal Bilimler Enstitüsü, İzmir.

Bakır, M. (2003). Denetim, Rize: Akademisyen Yayınevi.

Başkan, T. D. (2013), Muhasebe ve hata hilelerinin önlenmesinde bağımsız denetimin rolü ve etkinliği: bir uygulama. (Doktora Tezi). Kırıkkale Üniversitesi, Sosyal Bilimler Enstitüsü, Kırıkkale.

Dal, S., Çalış, E. (2013), Anonim şirketlerde bağımsız denetim ve bağımsız denetçi. Mali Çözüm Dergisi, 1 (118), S. 87-106.

Erken, H. (2009), Cisa, iç denetçi hazine müsteşarlığı, denetimde "bağımsızlık” kavramı. Denetişim, 1, 16-27.

Eroğlu, M. T. (2010). Global krizler sürecinde bankacılık sektöründe iç denetim sisteminin önemi ve Türkiye uygulaması. (Yüksek Lisans Tezi). Marmara Üniversitesi, Sosyal Bilimler Enstitüsü, İstanbul.

Gümrah, Ö. (2017), Bă̆ımsız denetim ve muhasebe meslek etiği: bağımsız denetçilerin etik ilkelere yaklaşımları üzerine bir araştırma. (Yüksek Lisans Tezi). Selçuk Üniversitesi, Sosyal Bilimler Enstitüsü, Konya.

Güredin, E. (2000). Denetim, İstanbul: Beta Yayınları. 
Kahyaoğlu, S. B. (2017), Yolsuzluğun önlenmesi ve etiğin teşviki için teknik destek projesi, iç kontrol ve etik ilişsisi çerçevesinde kamu kurumlarında etik kültürünün benimsenmesinde iç denetçilerin rolü, Teknik Rapor, https://İsletme.Bakircay.Edu.Tr/Yuklenenler/ Resimler/Iibf/Resimler/Teknik_Rapor_Tr.Pdf

Kavut, L., Taş, O., Şavlı, T. (2009). Uluslararası denetim standartları kapsamında bağımsız denetim, İstanbul: İSSMMO Yayınları.

Kepekçi, C. (2000). Bağımsız denetim. Ankara: Siyasal Yayınlar.

Keskin, D.A. (2016), İşletmelerin sürekliliğini sağlamada kritik öneme sahip risk yönetimi ve risk odaklı denetim yaklaşımı. Denetişim, (4), 38-46.

KGK. (2014). Bağımsız Denetçiler İçin Etik Kurallar. https://www.kgk.gov.tr/Portalv2Uploads/files/Duyurular/v2/TDS/TDS_2021_ Seti/2019_etikkurallar.pdf

Köksalan, N. (2019), Hediye verme davranışında duygusal tatmini etkileyen faktörlerin belirlenmesine yönelik nitel bir araştırma. (Yüksek Lisans Tezi). Sakarya Üniversitesi, İşletme Enstitüsü, Sakarya.

Köse, M.S. (2017), Hediye verme davranışında tatmini etkileyen faktörlerin belirlenmesine yönelik bir araştırma. (Doktora Tezi). Sakarya Üniversitesi, Sosyal Bilimler Enstitüsü, Sakarya.

Müslümov, A., Aras, G. (2002), Türkiye'de muhasebe ve finansal yönetim uygulamalarında etik davranışları etkileyen faktörlerin analizi, XXI. Muhasebe Eğitimi Sempozyumu, Bodrum.

Saxena, R. G., Srinivas, K., Rai, U., Rai, S. M. (2010). Auditing and business communications, India: Himalaya Pub. House.

Selimoğlu, S., Uzay, Ş., Uyar, S., Özbirecikli, M., Poroy Arsoy, A., Başar, B. (2012). Muhasebe denetimi ve mali analiz, Eskişehir: Anadolu Üniversitesi Yayınları.

Sermaye Piyasası Kurulu (SPK). (2006). Sermaye piyasasında bağımsız denetim standartları hakkında tebliğ, Resmi Gazete Sayısı: 26196.

Şeker A. (2019), Hediye ve hediye satın alma davranışları. Afyon Kocatepe Üniversitesi, Sosyal Bilimler Dergisi, 21(3), 869-887.

Ulucan Ö. F., Özdemir Z. (2014), Çalışan hilelerinin önlenmesinde proaktif yaklaşımlar: kurumsal işletmelerde insan kaynakları yöneticileri üzerine nitel bir araştırma. Öneri Dergisi, 10(40), 75-89.

Yavaşoğlu, M. (2001). Sermaye piyasası mevzuatında bağımsız denetim. Ankara: Seçkin Yayınları.

Yazar, B. B. (2021), Bağımsız denetçiler için etik kurallar ile faizsiz finans kuruluşları denetçileri için etik kuralların karşılaştırılması. Uluslararast Anadolu Sosyal Bilimler Dergisi, 5 (1), 100-126.

Yükçü, S. Ve Alkan, G. İ. (2020). Senaryolarla denetimde etik, Ankara: Detay Yayıncılık. 